\title{
Bromelain: an Overview of Applications in Medicine and Dentistry
}

\author{
Antonello Mameli ${ }^{1}$, Valentino Natoli ${ }^{2}$, Cinzia Casu ${ }^{3, *}$ \\ DDS, Department of Surgical Sciences, University of Cagliari, Italy; antonellomameli93@ gmail.com (A.M.); \\ DDS, Private Dental Practice, Fasano, Italy; valentinonatoliodn@gmail.com (V.N.); \\ DDS, Private Dental Practice, Cagliari, Italy; ginzia.85@hotmail.it (C.C.); \\ Correspondence: ginzia.85@hotmail.it;
}

Received: 9.05.2020; Revised: 12.07.2020; Accepted: 14.07.2020; Published: 19.07.2020

\begin{abstract}
Bromelain is an enzyme contained in the pineapple fruit, used previously for its antiinflammatory, anti-fibrinolytic, anti-edema activities. It also has an antibacterial and anti-metastatic action, and it is successfully used in the medical field. There are few research works on its administration on dentistry. However, it has been shown to be very effective in reducing swelling and post-operative edema in oral surgery, and it is also proposed for the treatment of caries and periodontal disease, with the aim to reduce collateral events of pharmacological therapy. We want to underline how its mechanism of action can make this molecule very important in the dental field.
\end{abstract}

Keywords: Bromelain; bromelain in oral medicine; bromelain in dentistry.

(C) 2020 by the authors. This article is an open-access article distributed under the terms and conditions of the Creative Commons Attribution (CC BY) license (https://creativecommons.org/licenses/by/4.0/).

\section{Introduction}

Bromelain is a proteolytic enzyme present in the plant of pineapple (Ananas comosus). It has been used for a long time in traditional medicine in South-east Asia, Kenya, India, and China because of its anti-inflammatory, anti-fibrinolytic, anti-thrombotic, and anti-edema properties [1]. Bromelain is present in the fruit and stem. It contains different endopeptidases, thiols, and other components such as phosphatase, glucosidase, peroxidase, glycoproteins, and protease inhibitors [2]. Currently, 8 active components of bromelain have been isolated, including the main components called F4 and F5, F9 represents $2 \%$ of total proteins and is the most active fraction [3]. Bromelain acts at a $\mathrm{pH}$ of 4.5-9.5 [4]. It is absorbed into the human intestine and remains biologically active with about 6-9 h half-life, reaching a peak $1 \mathrm{~h}$ after administration [5]. Various names have been used to indicate bromelain activity such as Rorer's unit (r.u.), gelatin dissolution unit (g.d.u.), and milk coagulation units (m.c.u.). These are the most common measures of activity used. One gram of bromelain standardized at 2000 m.c.u. would be approximately equal to 1 gram with 1200 g.d.u. and 8 grams would correspond to 100,000 r.u. of activity [6].

\section{Bromelain activity}

Bromelain has been shown to be effective both in several in vivo and in vitro studies. Its anti aggregating action has been demonstrated in patients with previous ischemic problems by decreasing the level of platelet aggregation in the blood in 17 out of 20 subjects examined and normalizing the values in 8 out of 9 subjects who previously had a high platelet 
aggregation value after $2 \mathrm{~h}$ after taking bromelain [7]. Previous in vitro studies have shown that bromelain led to a reduction in platelet aggregation and its activation by proteolytic activity [8,9], especially that of the F9 fraction. Its antiaggregant action also counteracts the formation of platelet agglomerates that can facilitate the metastasis of tumors because the platelet formation is stimulated by tumor cells allowing aggregations that make the action of the immune system difficult, so we can conclude that it has an anti-metastatic action [10-12]. Bromelain has also demonstrated anti-inflammatory action by inhibiting COX-2 expression and PGE2 production in murine microglial cells and human monocytic leukemia cell lines [13].

In addition, it modulates the expression of NF-kB responsible for the progression of the inflammatory state also in oncological subjects that, through COX 2 and PGE2 leads at the production of angiogenic factors [2,14]. In vitro bromelain has demonstrated the ability to modulate molecular surface adhesion on T cells, macrophages, and natural killer cells and also induces the secretion of IL-1 $\beta$, IL- 6 , and TNF $\alpha$ by the cells themselves $[15,16]$.

In addition, it appears to act by modulating the action of $\mathrm{T}$ lymphocytes by interfering in the transduction of the Raf-1 signal, which leads to the reduction of CD4+ Th cells by the inhibition of the CD25 expression (receptor for IL-2) [17,18]. Another recognized action of bromelain is its fibrinolytic capacity, which allows reducing plasma levels of fibrinogen and bradykinin, resulting in less edema and inflammation, thus allowing greater reabsorption of fluids at the interstitial level [19].

Bromelain also has an intrinsic antimicrobial activity tested against Escherichia coli and Vibrio cholerae by acting by modifying the receptor attack sites and influencing the intestinal secretion signaling pathways $[20,21]$. It seems that it was useful to promote the absorption of other drugs, including some antibiotics such as penicillin and tetracyclines [22]. Bromelain in combination with antibiotic administration has been shown to be more effective than antibiotics alone in the treatment of pneumonia, bronchitis, staphylococcal skin infections, thrombophlebitis, cellulitis, pyelonephritis and in perirectal and rectal abscesses, sinusitis and urinary tract infections. A combination of bromelain, trypsin, and rutin was administered as adjuvant therapy in combination with antibiotics for children with sepsis [23-26]. However, there are currently no studies performed on dental infections.

\section{Bromelain in the medical field}

Other studies have reported that bromelain prevented the formation of edema and reduced those already existing in a number of animal experiments [27]. As regards toxicity, bromelain has a very low level of toxicity which would make it less harmful than other antiinflammatory drugs such as cortisone and NSAIDs: according to one study [28], bromelain has a very low toxicity with an LD50 (lethal dose) greater than $10 \mathrm{~g} / \mathrm{kg}$ in mice, badgers, and rabbits. In dogs, the dose was increased to $750 \mathrm{mg} / \mathrm{kg}$ without showing toxic effects over time. In a human study, bromelain was administered with a dosage of 3000 FIP units/day over a period of 10 days, and no side effects were found [29]. It was also used in the treatment of patients with osteoarthritis in two formulations: one 90mg and one $45 \mathrm{mg}$ and in both cases there was a reduction in inflammation and pain compared to standard treatments, but it remained well tolerated and without the presence of common side effects in other antiinflammatory drugs [19]. However, the data are conflicting, as, at high doses, bromelain could give gastrointestinal problems [30] and allergic reactions [31,32]. 


\section{Bromelain in dentistry}

In dentistry, bromelain has been used for its anti-inflammatory action, especially after extraction of third molars in comparison or in association with other anti-inflammatory drugs. A study performed compared bromelain (100mg for 4-7 days) with placebo, administered in the same way. Although there is no great statistical difference, the bromelain group showed a decrease in inflammation and pain compared to the placebo group [33]. In the study of Odresi et al., bromelain ( $50 \mathrm{mg}$ every $12 \mathrm{~h}$ for 7 days) was compared with paracetamol in patients who performed third molar surgery. In the group who took bromelain, less inflammation was seen compared to the group who took paracetamol [34]. In a study carried out by Majid and colleagues, a comparison was made between bromelain and diclofenac where it was seen that the administration of $250 \mathrm{mg}$ of bromelain $6 \mathrm{~h}$ before surgery and for the following 4 days has an analgesic and anti-inflammatory action comparable to that of diclofenac $(25 \mathrm{mg})$ after moral third molar surgery [35]. The study carried out by Ghensi et al. comparing dexamethasone 4mg with $40 \mathrm{mg}$ of bromelain (taken every $6 \mathrm{~h}$ starting immediately after the surgical therapy), showed that bromelain is effective in reducing edema but is lower than dexamethasone. However, the anti-edema and anti-inflammatory effects increased by combining dexamethasone and bromelain[36]. In another study, bromelain (40mg every $6 \mathrm{~h}$ for 6 days) was compared with ketoprofen (100mg), and there was no significant difference [37]. From this, it can be inferred that they have an efficacy comparable to common anti-inflammatory drugs while presenting lower toxicity. A recent literature review has shown that bromelain is effective in reducing inflammation and edema. However, some limitations remain, such as a consensus on bromelain dosages [38]. It was successfully proposed against teeth caries [39] and also against periodontal pathogen for its antibacterial activity [40]. A meta-analysis in 2019 confirms its beneficial action in the extraction of third molars [41].

\section{Conclusion}

The previous interesting review had analyzed the anti-cancer effects of natural products [42]. Bromelain has anti-inflammatory, anti-tumor, anti-metastatic, antibacterial, anti-edema activity, in the face of almost zero side effects. The use of bromelain-based supplements could be increased in dentistry, and more studies should be performed to establish adequate dosages and protocols.

\section{Funding}

This research received no external funding.

\section{Acknowledgments}

This research has no acknowledgment.

\section{Conflicts of Interest}

The authors declare no conflict of interest. 


\section{References}

1. Saptarini, N.M.; Rahayu, D.; Herawati, I. Antioxidant Activity of Crude Bromelain of Pineapple (Ananas comosus (L.) Merr) Crown from Subang District, Indonesia. J Pharm Bioallied Sci. 2019, 11 (Suppl 4), S551S555, https://doi.org/10.4103/jpbs.JPBS_200_19.

2. Pavan, R.; Jain, S.; Shraddha; Kumar, A. Properties and Therapeutic Application of Bromelain: A Review. Biotechnology Research International 2012, 2012, https://doi.org/10.1155/2012/97620.

3. de Lencastre Novaes, L.C.; Jozala, A.F.; Lopes, A.M.; de Carvalho Santos-Ebinuma, V.; Mazzola, P.G.; Pessoa Junior, A. Stability, purification, and applications of bromelain: A review. Biotechnology Progress 2016, 32, 5-13, https://doi.org/10.1002/btpr.2190.

4. Nwagu, T.N.; Ugwuodo, C.J. Stabilizing bromelain for therapeutic applications by adsorption immobilization on spores of probiotic Bacillus. International Journal of Biological Macromolecules 2019, 127, 406-414, https://doi.org/10.1016/j.ijbiomac.2019.01.061.

5. Xu, X.; Liu, R.; Guo, P.; Luo, Z.; Cai, X.; Shu, H.; Ge, Y.; Chang, C.; Fu, Q. Fabrication of a novel magnetic mesoporous molecularly imprinted polymer based on pericarpium granati-derived carrier for selective absorption of bromelain. Food Chemistry 2018, 256, 91-97, http://doi.org/10.1016/j.foodchem.2018.02.118.

6. Bromelain. Monograph. Altern Med Rev 2010, 15, 361-368.

7. Ley, C.M.; Tsiami, A.; Ni, Q.; Robinson, N. A review of the use of bromelain in cardiovascular diseases. Zhong xi yi jie he xue bao = Journal of Chinese integrative medicine 2011, 9, 702-710.

8. Passali, D.; Passali, G.C.; Bellussi, L.M.; Sarafoleanu, C.; Loglisci, M.; Manea, C.; Iosif, C.; Passali, F.M. Bromelain's penetration into the blood and sinonasal mucosa in patients with chronic rhinosinusitis. Acta Otorhinolaryngol Ital. 2018, 38, 225-228, https://doi.org/10.14639/0392-100X-1693.

9. Kaur, H.; Corscadden ,K.; Lott, C., Elbatarny ,H.S.; Othman, M. Bromelain has paradoxical effects on blood coagulability: a study using thromboelastography. Blood Coagulation \& Fibrinolysis 2016, 27, 745-752, https://doi.org/10.1097/MBC.0000000000000244.

10. Kalra, N.; Bhui, K.; Roy, P.; Srivastava, S.; George, J.; Prasad, S.; Shukla, Y. Regulation of p53, nuclear factor $\mathrm{\kappa B}$ and cyclooxygenase-2 expression by bromelain through targeting mitogen-activated protein kinase pathway in mouse skin. Toxicology and Applied Pharmacology 2008, 226, 30-37, https://doi.org/10.1016/j.taap.2007.08.012.

11. Schlesinger, M. Role of platelets and platelet receptors in cancer metastasis. Journal of Hematology \& Oncology 2018, 11, https://doi.org/10.1186/s13045-018-0669-2.

12. Bhui, K.; Tyagi, S.; Srivastava, A.K.; Singh, M.; Roy, P.; Singh, R.; Shukla, Y. Bromelain inhibits nuclear factor kappa-B translocation, driving human epidermoid carcinoma A431 and melanoma A375 cells through G(2)/M arrest to apoptosis. Mol Carcinog 2012, 51, 231-243, https://doi.org/10.1002/mc.2076.

13. Debnath, R.; Chatterjee, N.; Das, S.; Mishra, S.; Bose, D.; Banerjee, S.; Das, S.; Saha, K.D.; Ghosh, D.; Maiti, D. Bromelain with peroxidase from pineapple are more potent to target leukemia growth inhibition A comparison with only bromelain. Toxicology in Vitro 2019, 55, 24-32, https://doi.org/10.1016/j.tiv.2018.11.004.

14. Müller, S.; März, R.; Schmolz, M.; Drewelow, B.; Eschmann, K.; Meiser, P. Placebo-controlled Randomized Clinical Trial on the Immunomodulating Activities of Low- and High-Dose Bromelain after Oral Administration - New Evidence on the Antiinflammatory Mode of Action of Bromelain. Phytotherapy Research 2013, 27, 199-204, https://doi.org/10.1002/ptr.4678.

15. Schulz, A.; Fuchs, P.C.; Oplaender, C.; Valdez, L.B.; Schiefer, J.L. Effect of Bromelain-Based Enzymatic Debridement on Skin Cells. Journal of Burn Care \& Research 2018, 39, 527-535, https://doi.org/10.1093/jbcr/irx011.

16. Chandanwale, A.; Langade, D.; Sonawane, D.; Gavai, P. A Randomized, Clinical Trial to Evaluate Efficacy and Tolerability of Trypsin:Chymotrypsin as Compared to Serratiopeptidase and Trypsin:Bromelain:Rutoside in Wound Management. Advances in Therapy 2017, 34, 180-198, https://doi.org/10.1007/s12325-016-0444-0.

17. Chobotova, K.; Vernallis, A.B.; Majid, F.A.A. Bromelain's activity and potential as an anti-cancer agent: Current evidence and perspectives. Cancer Letters 2010, 290, 148-156, https://doi.org/10.1016/j.canlet.2009.08.001.

18. Secor, E.R., Jr.; Shah, S.J.; Guernsey, L.A.; Schramm, C.M.; Thrall, R.S. Bromelain limits airway inflammation in an ovalbumin-induced murine model of established asthma. Alternative therapies in health and medicine 2012, 18, 9-17.

19. Brien, S.; Lewith, G.; Walker, A.; Hicks, S.M.; Middleton, D. Bromelain as a Treatment for Osteoarthritis: a Review of Clinical Studies. Evidence-Based Complementary and Alternative Medicine 2004, 1, 251-257, https://doi.org/10.1093/ecam/neh035.

20. Ghanbari, R.; Ebrahimpour, A. Separation and identification of bromelain-generated antibacterial peptides from Actinopyga lecanora. Food Science and Biotechnology 2018, 27, 591-598, https://doi.org/10.1007/s10068-017-0267-z. 
21. Muntari, B.; Amid, A.; Mel, M.; Jami, M.S.; Salleh, H.M. Recombinant bromelain production in Escherichia coli: process optimization in shake flask culture by response surface methodology. AMB Express 2012, 2, https://doi.org/10.1186/2191-0855-2-12.

22. Belcher, M.D.; Kaddour-Djebbar, I.; Bollag, W.B.; Davis, L.S. The proteolytic effect of bromelain on bullous pemphigoid antigen-2. Journal of the American Academy of Dermatology 2016, 75, 838-840, https://doi.org/10.1016/j.jaad.2016.05.025.

23. Tan, Y.; Li, P. Bromelain has significant clinical benefits after extraction of the third molar during chemotherapy in patients with hematologic tumor. Oncol Lett 2018, 15, 2962-2966, https://doi.org/10.3892/ol.2017.767.

24. Büttner, L.; Achilles, N.; Böhm, M.; Shah-Hosseini, K.; Mösges, R. Efficacy and tolerability of bromelain in patients with chronic rhinosinusitis - A pilot study. B-ENT 2013, 9, 217-225.

25. Ataide, J.A.; de Carvalho, N.M.; Rebelo, M.d.A.; Chaud, M.V.; Grotto, D.; Gerenutti, M.; Rai, M.; Mazzola, P.G.; Jozala, A.F. Bacterial Nanocellulose Loaded with Bromelain: Assessment of Antimicrobial, Antioxidant and Physical-Chemical Properties. Scientific Reports 2017, 7, https://doi.org/10.1038/s41598017-18271-4.

26. Cai, T.; Tiscione, D.; Gallelli, L.; Verze, P.; Palmieri, A.; Mirone, V.; Bartoletti, R.; Malossini, G. Serenoa repens associated with selenium and lycopene extract and bromelain and methylsulfonylmethane extract are able to improve the efficacy of levofloxacin in chronic bacterial prostatitis patients. Arch Ital Urol Androl. 2016, 88, 177-182, https://doi.org/10.4081/aiua.2016.3.177.

27. Bayat, S.; Amiri, N.; Pishavar, E.; Kalalinia, F.; Movaffagh, J.; Hashemi, M. Bromelain-loaded chitosan nanofibers prepared by electrospinning method for burn wound healing in animal models. Life Sci. 2019, 229, 57-66, https://doi.org/10.1016/j.lfs.2019.05.028.

28. Mohamed Tap, F.; Abd Majid, F.A.; Ismail, H.F.; Wong, T.S.; Shameli, K.; Miyake, M.; Ahmad Khairudin, N.B. In Silico and In Vitro Study of the Bromelain-Phytochemical Complex Inhibition of Phospholipase A2 (Pla2). Molecules 2018, 23, https://doi.org/10.3390/molecules23010073.

29. Sahbaz, A.; Aynioglu, O.; Isik, H.; Ozmen, U.; Cengil, O.; Gun, B.D.; Gungorduk, K. Bromelain: A natural proteolytic for intra-abdominal adhesion prevention. International Journal of Surgery 2015, 14, 7-11, https://doi.org/10.1016/j.ijsu.2014.12.024.

30. Soheilifar, S.; Bidgoli, M.; Hooshyarfard, A.; Shahbazi, A.; Vahdatinia, F.; Khoshkhooie, F. Effect of Oral Bromelain on Wound Healing, Pain, and Bleeding at Donor Site Following Free Gingival Grafting: A Clinical Trial. J Dent (Tehran) 2018, 15, 309-316.

31. Secor, E.R.; Szczepanek, S.M.; Castater, C.A.; Adami, A.J.; Matson, A.P.; Rafti, E.T.; Guernsey, L.; Natarajan, P.; McNamara, J.T.; Schramm, C.M.; Thrall, R.S.; Silbart, L.K. Bromelain Inhibits Allergic Sensitization and Murine Asthma via Modulation of Dendritic Cells. Evidence-Based Complementary and Alternative Medicine 2013, 2013, https://doi.org/10.1155/2013/702196.

32. Ho, D.; Jagdeo, J.; Waldorf, H. Is There a Role for Arnica and Bromelain in Prevention of Post-Procedure Ecchymosis or Edema? A Systematic Review of the Literature. Dermatologic surgery : official publication for American Society for Dermatologic Surgery [et al.] 2016, 42, 445-463, https://doi.org/10.1097/DSS.0000000000000701.

33. de la Barrera-Nunez, M.C.; Yanez-Vico, R.M.; Batista-Cruzado, A.; Heurtebise-Saavedra, J.M.; Castillo-de Oyague, R.; Torres-Lagares, D. Prospective double-blind clinical trial evaluating the effectiveness of Bromelain in the third molar extraction postoperative period. Med Oral Patol Oral Cir Bucal 2014, 19, e157-162, https://doi.org/10.4317/medoral.19105.

34. Ordesi, P.; Pisoni, L.; Nannei, P.; Macchi, M.; Borloni, R.; Siervo, S. Therapeutic efficacy of bromelain in impacted third molar surgery: a randomized controlled clinical study. Quintessence Int 2014, 45, 679-684, https://doi.org/10.3290/j.qi.a32237.

35. Majid, O.W.; Al-Mashhadani, B.A. Perioperative Bromelain Reduces Pain and Swelling and Improves Quality of Life Measures After Mandibular Third Molar Surgery: A Randomized, Double-Blind, PlaceboControlled Clinical Trial. Journal of Oral and Maxillofacial Surgery 2014, 72, 1043-1048, https://doi.org/10.1016/j.joms.2013.12.035.

36. Ghensi, P.; Cucchi, A.; Creminelli, L.; Tomasi, C.; Zavan, B.; Maiorana, C. Effect of Oral Administration of Bromelain on Postoperative Discomfort After Third Molar Surgery. Journal of Craniofacial Surgery 2017, 28. e191-e197, https://doi.org/10.1097/SCS.0000000000003154.

37. Inchingolo, F.; Tatullo, M.; Marrelli, M.; Inchingolo, A.M.; Picciariello, V.; Inchingolo, A.D.; Dipalma, G.; Vermesan, D.; Cagiano, R. Clinical trial with bromelain in third molar exodontia. Eur Rev Med Pharmacol Sci 2010, 14, 771-774.

38. Liu, S.; Zhao, H.; Wang, Y.; Zhao, H.; Ma, C. Oral Bromelain for the Control of Facial Swelling, Trismus, and Pain After Mandibular Third Molar Surgery: A Systematic Review and Meta-Analysis. Journal of Oral and Maxillofacial Surgery 2019, 77, 1566-1574, https://doi.org/10.1016/j.joms.2019.02.044.

39. Reddy, V.K.; Nagar, P.; Reddy, S.; Ragulakollu, R.; Tirupathi, S.P.; Ravi, R.; Purumadla, U. Bromelain vs Papain Gel for Caries Removal in Primary Teeth. The journal of contemporary dental practice 2019, 20, 1345-1349. 
40. Praveen, N.C.; Rajesh, A.; Madan, M.; Chaurasia, V.R.; Hiremath, N.V.; Sharma, A.M. In vitro Evaluation of Antibacterial Efficacy of Pineapple Extract (Bromelain) on Periodontal Pathogens. J Int Oral Health 2014, 6, 96-98.

41. Mendes, M.L.; do Nascimento-Júnior, E.M.; Reinheimer, D.M.; Martins-Filho, P.R. Efficacy of proteolytic enzyme bromelain on health outcomes after third molar surgery. Systematic review and meta-analysis of randomized clinical trials. Med Oral Patol Oral Cir Bucal. 2019, 24, e61e69,https://doi.org/10.4317/medoral.22731.

42. Gobind R., Var Ruchi S., Imran S., Atul S., Diwakar A., Anil K S.. Anti-cancer potential of natural products: recent trends, scope and relevance. Letters in Applied NanoBioScience 2020, 9, 902 - 907, https://doi.org/10.33263/LIANBS91.902907. 